\title{
EFEKTIVITAS PERENCANAAN PEMBANGUNAN DAERAH KOTA BATU
}

\author{
Dekki Umamur Ra'is, Dody Setyawan, dan Yordanus Dimus \\ Program Studi Administrasi Publik, FISIP Universitas Tribhuwana Tunggadewi \\ e-mail: deckyvanmaduro@gmail.com
}

\begin{abstract}
Abstrak: Keberhasilan pembangunan negara tidak semata-mata ditentukan oleh kekayaan sumber daya alam yang melimpah, tetapi juga ditentukan oleh proses perencanaan pembangunan yang sistematis, terukur, dan menyeluruh (komprehensif). Perencanaan pembangunan memiliki peran yang sangat strategis dan vital dalam pembangunan. Keberhasilan perencanaan, salah satunya diukur dari efektifitasnya. Ada empat indikator efektivitas, yaitu Ketepatan Waktu, Ketepatan perhitungan biaya, Ketepatan Dalam Menentukan Tujuan, dan Ketepatan Sasaran. Penelitian in menggunakan pendekatan kualitatif dengan penentuan informan menggunakan metode snowball sampling dan analisa data menggunakan triangulasi. Hasil kajian menunjukkan bahwa perencanaan pembangunan daerah di Kota Batu sudah efektif. Walaupun begitu, masih ada beberapa faktor penghambat yang harus diperhatikan oleh pemerintah kota Batu, yaitu program kegiatan yang tidak sesuai dengan RPJMD atau visi-misi kepala daerah, sistem ditingkat lokal pemerintahan daerah yang belum tersinkronisasi secara maksimal, sehingga proses input data masih perlu berulang-ulang. Faktor lainnya adalah kurangnya koordinasi antar OPD. Oleh sebab itu diperlukan konsistensi dari semua elemen yang terlibat dalam perencanaan. Komitmen dari kepala daerah, kepala OPD dan elemen lain yang terlibat dalam proses perencanaan harus diperkuat.
\end{abstract}

Kata Kunci: Efektifitas; Perencanaan; Pembangunan; Daerah; Pemerintahan

\begin{abstract}
The quality of a country's growth is decided not just by the availability of plentiful natural resources but also by a formal, tangible and rigorous method of development planning. Planning for construction plays a very pragmatic and vitally significant position in planning. Planning performance, in which one is calculated by its effectiveness. There are 4 efficacy metrics, that' Timeliness, Accuracy in costs, Accuracy in Setting Goals, and Accuracy of Targets. There are four effectiveness measures, which is timeliness, expense accuracy, objective setting accuracy, and aim accuracy. This research uses a qualitative methodology and the snowball sampling process to pick the informant and use triangulation as interpretation of the results. The results showed that regional development planning in Batu had been effective. Even so, there are still some inhibiting factors that must be considered by the local government, the program of activities that are not in accordance with the RPJMD or the vision and mission of the regional head, the system at the local level of the local government that has not been synchronized maximally, so the data input process still needs be repeated. Another factor is the lack of coordination among the OPD. It requires continuity with all the components involved in preparation. Commitments will be reinforced from department leaders, manager level and other aspects participating in the planning phase.
\end{abstract}

Key Words: Effectiveness; Planning; Development; Regional; Government; Governance

\section{PENDAHULUAN}

Keberhasilan pembangunan merupakan salah satu tolak ukur kesejahteraan negara. Pembangunan secara umum dapat berupa sumber daya manusia, pembangunan infrastruktur, dan pembangunan ekonomi. Kekayaan sumber daya alam bukanlah satu-satunya penentu keberhasilan pembangunan negara. Ada faktor lain yang bisa menjadi garansi keberhasilan pembangunan yaitu perencanaan pembangunan yang sistematis, terukur, menyeluruh, dan holistik. 
Perencanaan pembangunan memiliki peran yang sangat strategis dan posisi yang vital dalam pembangunan. Perencanaan merupakan aktivitas yang dilakukan oleh lembaga dan masyarakat yang dilakukan dengan sungguh-sungguh untuk menghasilkan strategi yang optimal guna mencapai sejumlah tujuan yang diinginkan (Mahi dan Trigunarso, 2017). Sedangkan menurut Prajudi (dalam Syafiie, 2015), planing merujuk pada perhitungan dan penentuan untuk mencapai objektif tertentu, kaitannya dengan tempat, waktu, pelaku, dan tata cara yang akan digunakan, sehingga bisa menjadi modal dasar dalam penyusunan dokumen perencanaan pembangunan ke depannya.

Dalam konteks pembangunan nasional, perencanaan pembangunan tidak selalu menjadi urusan pemerintah nasional. Melalui bingkai otonomi daerah, pemerintah daerah memiliki kewajiban untuk merancang perencanaan pembangunan daerahnya. Otonomi daerah adalah hak, wewenang, dan kewajiban daerah untuk mengatur dan mengurus rumah tangganya sendiri sesuai dengan peraturan perundang-undangan yang berlaku. Dengan adanya otonomi daerah, diharapkan tidak ada lagi perilaku politik otoritarian pemerintah pusat yang diartikulasikan dalam frase pusat daerah sehingga menimbulkan kesenjangan atau ketimpangan antara pusat dan daerah. Melalui otonomi daerah pemerintah daerah memiliki kewenangan untuk mensejahterakan rakyatnya. Konskwensinya, pemerintah daerah juga berkewajiban untuk menyediakan pelayanan publik, meningkatkan peran serta masyarakat dalam pembangunan, prakarsa, dan upaya pemberdayaan masyarakat lain. Otonomi daerah telah memberikan keleluasaan kepada daerah berupa discretionary power dalam menyelenggarakan pemerintahan daerahnya dengan mempertimbangkan prakarsa daerah, kreativitas daerah, karakteristik daerah, dan peran aktif masyarakat daerah untuk memajukan, mensejahterakan, dan mengembangkan daerahnya.

Relasi antara otonomi daerah dan perencanaan pembangunan daerah menjadi sangat kuat. Untuk bisa menangkap peluang yang terkandung dalam otonomi daerah, maka daerah harus menyusun perencanaan pembangunannya dengan baik. Dalam UU Nomor 25 Tahun 2004 yang menjadi landasan dalam penyusunan perencanaan pembangunan menjadikan perencanaan pembangunan daerah sebagai bagian integral dari perencanaan nasional. Maka, efektif atau tidaknya perencanaan pembangunan daerah berdampak langsung pada efektifitas perencanaan pembangunan. Perencanaan Pembangunan merupakan serangkaian kegiatan penyusunan tahapan kegiatan yang melibatkan para pemangku kepentingan daerah, tujuannya untuk menentukan manfaat dan mengalokasikan sumber daya daerah, serta berdasarkan potensi yang dimiliki, sebagai upaya untuk meningkatkan kesejahteraan masyarakat dalam suatu lingkungan/wilayah dalam jangka waktu tertentu. Pelaksanaan tata cara dan tahapan perencanaan pembangunan daerah bertujuan untuk mengefektifkan proses pemerintahan yang baik melalui pemanfaatan sumber daya publik yang berdampak pada tercapainya pembangunan yang baik.

Dalam konteks pembangunan negara, perencanaan pembangunan daerah harus saling terhubung dengan sistem perencanaan pembangunan nasional. Undang-undang Nomor 23 Tahun 2014 tentang Pemerintah Daerah, Peraturan Pemerintah Nomor 38 Tahun 2007 Tentang Pembagian Urusan Pemerintahan Antara Pemerintah, Pemerintahan Daerah Provinsi, Dan Pemerintahan Daerah Kabupaten/Kota, Peraturan Pemerintah Daerah Provinsi Jawa Timur Nomor 1 tentang Perubahan atas Peraturan Daerah Provinsi Jawa Timur Nomor 3 Tahun 2014 Tentang Rencana Pembangunan Jangka Menengah Daerah (RPJMD) Provinsi Jawa Timur Tahun 2014-2019, dan Peraturan Pemerintah Nomor 41 Tahun 2007 tentang Organisasi Perangkat Daerah, telah mengatur tentang pelimpahan urusan pusat kepada Daerah untuk melaksanakan urusan pemerintahan.

Badan Perencanaan Pembangunan, Penelitian dan Pengembangan Daerah merupakan unsur penyelenggara pemerintah daerah yang memiliki tanggung jawab untuk merumuskan dan menyusun perencanaan pembangunan daerah. Pemerintah daerah harus menghasilkan dokumen perencanaan 
pembangunan berupa dokumen Rencana Pembangunan Jangka Panjang Daerah (RPJPD), Rencana Pembangunan Jangka Menengah Daerah (RPJMD), Rencana Kerja Pemerintah Daerah (RKPD), dan dokumen perencanaan pembangunan yang dibuat oleh OPD seperti dokumen Rencana Strategis Satuan Kerja Perangkat Daerah (Renstra) dan dokumen Rencana Kerja SKPD (Renja SKPD).

Perencanaan pembangunan yang baik adalah perencanaan yang mampu menghasilkan output yang berdampak positif besar terhadap kesejahteraan masyarakat di berbagai bidang, sehingga apa yang menjadi masalah dalam perencanaan maupun pembangunan mampu bisa diselesaikan dengan adanya rencana pembangunan yang efektif. Maka, efektifitas dalam perencanaan pembangunan menjadi salah satu faktor penentu dalam menjawab kebutuhan masyarakat dan strategi pemenuhan janji politik kepala daerah.

\section{METODE PENELITIAN}

Penelitian ini merupakan penelitian kualitatif. Pendekatan kualitatif merupakan metode yang berakar dari filsafat positivisme yang digunakan untuk mengkaji obyek alamiah. Dalam pendekatan ini, peneliti merupakan instrumen kunci dari penelitian. Metode pengumpulan datanya menggunakan triangulasi, analisanya bersifat induktif, dan lebih mengutamakan makna daripada generalisasi seperti dalam pendekatan kuantitatif (Sugiyono, 2018). Seperti yang disampaikan oleh Moleong (2018) Pendekatan ini berusaha memahami fenomena (perilaku, persepsi, motivasi, tindakan, tanggapan dan lain-lain) yang dilakukan secara holistik, dan di deskripsikan dengan menggunakan metode ilmiah. Dalam kajian ini, peneliti ingin memahami lebih dalam mengenai efektivitas perencanaan pembangunan daerah kota batu.

Fokus pada penelitian ini, berdasarkan permasalahan yang terkait dengan teori-teori yang telah ada. Dalam menentukan indikator efektivitas, peneliti menggunakan teori yang dikembangkan oleh Makmur (2011), yaitu, ketepatan waktu, ketepatan perhitungan biaya, ketepatan dalam menentukan tujuan dan ketepatan sasaran. Adapun yang menjadi fokus dalam penelitian ini adalah bagaimana Ketepatan Waktunya, ketepatan dalam perhitungan biayanya, ketepatan dalam menentukan tujuan, dan bagaimana ketepatan Sasarannya.

Penelitian ini menggunakan teknik sampling dengan snowball sampling, yaitu teknik penentuan sampel sumber data yang awalnya sedikit lama-lama menjadi besar. Hal tersebut dipilih mengingat jumlah sumber data yang terbatas, sehingga dianggap belum mampu memberikan informasi yang valid dan mencukupi, maka informan yang lain sangat dibutuhkan untuk mendapatkan informasi terkait yang akan diteliti. Informan adalah mereka yang menguasai atau memahami mengenai objek yang menjadi sasaran penelitian, pemilihan informan juga harus benar-benar orang yang dianggap menguasai situasi sosial yang diteliti agar dapat memperoleh informasi yang valid (Faisal dalam Sugiyono, 2018).

Adapun instrumen dalam penelitian ini terdiri dari peneliti, pedoman wawancara, dan catatan lapangan. Sementara, data yang digunakan adalah data primer dan data sekunder. Data dikumpulkan melalui wawancara terstruktur, pengamatan, dan dokumentasi. Selanjutnya dilakukan analisa data melalui tahapan reduksi data, penyajian data, dan penarikan kesimpulan. Proses Triangulasi dilakukan untuk menjamin keabsahan data, yaitu teknik pengumpulan data yang berbeda-beda untuk mendapatkan data dari sumber yang sama.

\section{PEMBAHASAN}

\section{Efektivitas Perencanaan Pembangunan Daerah Kota Batu}

Guna mewujudkan tujuan jangka panjang dan jangka pendek Kota Batu serta untuk memenuhi tuntutan peraturan yang berlaku, maka Pemerintah Kota Batu mempunyai kewajiban untuk menyusun 
perencanaan pembangunan. Perencanaan Pembangunan Daerah merupakan salah satu tahapan penyusunan kegiatan pembangunan dengan melibatkan para pemangku kepentingan, tujuannya untuk memanfaatkan dan mengalokasikan sumber daya yang sudah ada agar bisa digunakan untuk meningkatkan kesejahteraan sosial masyarakat dalam suatu lingkungan wilayah (daerah) tertentu dalam jangka waktu tertentu yang telah ditentukan. Selain itu, kegiatan penyusunan perencanaan pembangunan bertujuan untuk merealisasikan Visi dan Misi kepala Daerah.

Dalam praktiknya, di Kota Batu, perencanaan dibuat untuk digunakan sebagai bahan acuan pelaksanaan kegiatan pembangunan yang hendak dilaksanakan. Selain itu, perencanaan pembangunan daerah bertujuan untuk memberikan kepastian operasionalisasi dan peran masing-masing OPD dalam mewujudkan visi dan misi yang telah ditetapkan sebelumnya. Perencanaan Pembangunan Kota Batu dilakukan dengan melakukan beberapa tahapan berikut:

1. Melakukan analisa secara berterusan terhadap kondisi nyata daerah dan pelaksanaan pembangunan tahun sebelumnya.

2. Membuat prediksi terhadap semua potensi yang dimiliki daerah dan prospek apa saja yang memiliki kemungkinan akan berkembang dimasa depan. Prediksi dilakukan terhadap kondisi nyata daerah dan masyarakat, baik itu di lingkungan internal maupun lingkungan eksternalnya.

3. Membuat rumusan tujuan dan kebijakan (penyelarasan) pembangunan daerah dengan mengacu pada pedoman pembangunan yang ada ditingkat atasnya.

4. Membuat strategi pemecahan masalah (problem solving) dengan membuat skala prioritas terhadap program-program (kegiatan) pembangunan daerah.

Perencanaan Pembangunan Daerah Kota Batu mengacu pada UU No. 25 Th. 2004 tentang Sistem Perencanaan Pembangunan Nasional (SPPN). Dalam UU tersebut pemerintah berkewajiban untuk menyusun dokumen perencanaan pembangunan sesuai dengan kewenangan daerahnya masingmasing (Pasal 3 Ayat 2). Hasilnya, ketika menyusun perencanaan, maka harus ada produk berupa dokumen seperti dokumen RPJPD, dokumen RPJMD, dan dokumen RKPD.

Perencanaan Pembangunan Kota Batu merupakan hasil dari usaha yang dilakukan secara sistematis, integral, tersinkronisasi, dan berkesinambungan. Selanjutnya, hasil dari perencanaan tersebut akan dilaksanakan oleh masing-masing OPD serta para pemangku kepentingan dengan memanfaatkan atau memaksimalkan setiap sumber daya yang sudah dialokasikan dalam perencanaan pembangunan secara optimal, efektif, efisien, dan bisa dipertanggungjawabkan. Sehingga, dampak dari perencanaan pembangunan tersebut mampu meningkatkan kualitas hidup warga Kota Batu secara berkelanjutan. Sehingga dalam pelaksanaan pembangunan daerah Pemerintah Kota Batu selalu berupaya agar kegiatan perencanaan bisa terlaksana dengan efektif dan efisien. Efektivitas merpakan ketepatan dalam mencapai tujuan, hasil maupun ketepatan dalam pembiayaan sebuah kegiatan. Sehingga untuk melihat seberapa jauh efektivitas Perencanaan Pembangunan Daerah Kota Batu akan dilihat berdasarkan ketepatan waktu, ketepatan dalam menentukan tujuan dan ketepatan sasaran, indikator tersebut yang akan digunakan peneliti sebagai tolak ukur Efektivitas Perencanaan Pembangunan Daerah Kota Batu.

Proses Perencanaan yang disusun oleh pemerintah kota kemudian dijadikan dasar pembangunan tahunan dalam berbagai macam bentuk dokumen perencanaan pembangunan seperti yang telah ditetapkan dalam peraturan yang berlaku secara nasional seperti Rencana Kerja Pembangunan Daerah (RKPD). Dokumen tersebut merupakan turunan (penjabaran) dari dokumen RPJMD yang akan digunakan dalam kurun waktu satu tahun. RKPD berisi prioritas pembangunan daerah, kerangka pembangunan ekonomi daerah, rencana kerja Pemkot dan pendanaan kegiatan yang mengacu pada dokumen Rencana Kerja Pemerintah (RKP). Ketika menyusun RKPD Pemerintah Kota 
Batu mengacu pada Permendagri No. 54 Th. 2010 tentang Pelaksanaan PP No. 8 Th. 2008 Tentang Tahapan, Tata Cara Penyusunan, Pengendalian Dan Evaluasi Pelaksanaan Rencana Pembangunan Daerah. Aturan tersebut digunakan untuk mengevaluasi capaian kinerja pembangunan tahun sebelumnya, mengukur fenomena yang sedang terjadi pada saat tahun berjalan, isu-isu strategis yang kemungkinan akan ditemui (dihadapi) pada saat pelaksanaan, faktor hubungan antar sektor kelembagaan, antar organisasi dan antar wilayah serta penyerapan usulan publik yang dilakukan bertahap melalui forum Musyawarah Perencanaan Pembangunan (Musrenbang). Pelaksanaan Musrenbang dimulai dari tingkat lembaga masyarakat paling bawah yakni Desa atau Kelurahan, kemudian di tingkat Kecamatan, dan terakhir ditingkat daerah melalui forum Musrenbang RKPD Kota Batu. Sebagai dokumen perencanaan pembangunan tahunan, RKPD harus dapat menjawab tuntutan yang menjadi kebutuhan masyarakat Kota Batu terutama berdasarkan kondisi obyektif atas isu-isu strategis pembangunan yang berkembang. Dalam pelaksanaan perencanaan pembangunan tentu ada beberapa hal yang harus diperhatikan oleh pemerintah Kota Batu agar dalam pelaksanaannya dapat berjalan dengan efektif.

Berdasarkan penyajian data sebelumnya dijelaskan bahwa Pemerintah Kota Batu telah melaksanakan kegiatan perencanaan pembangunan sesuai dengan ketentuan waktu yang telah ditentukan. Pelaksanaan Musrenbang RKPD Kota Batu dilaksanakan pada bulan Maret minggu ke empat, waktu pelaksanaannya juga sesuai dengan Peraturan Menteri Dalam Negeri Nomor 86 tahun 2017, yaitu pelaksanaan musrenbang RKPD tingkat Kabupaten/Kota dilaksanakan paling lambat pada minggu ke 4 (empat) bulan Maret. Hasil dari musrenbang dirumuskan dalam berita acara kesepakatan dan ditanda tangani oleh unsur yang mewakili pemangku kepentingan yang tentang Tata Cara Perencanaan, Pengendalian dan Evaluasi Pembangunan Daerah Pasal 94 Ayat (4) menjelaskan bahwa, pelaksanaan Musrenbang Rencana Kegiatan Pembangunan Daerah menghadiri musrenbang RKPD pada tingkat Kabupaten/Kota.

Sehingga berdasarkan hasil penyajian data yang diperoleh, perencanaan pembangunan daerah kota batu yang dilaksanakan oleh Bappelitbangda Kota Batu dari segi ketepatan waktu sudah dapat dikatakan efektif. Sebuah perencanaan pembangunan dapat dikatakan efektif apabila perencanaan tersebut dilaksanakan sesuai dengan waktu yang telah ditentukan. Bukan hanya itu saja, hasil dari perencanaan yang dilakukan juga menjadi salah satu bukti agar perencanaan dapat dikatakan efektif.

Perencanaan Pembangunan Daerah merupakan proses awal dari serangkaian kegiatan pembangunan baik itu ditingkat pusat maupun daerah. Oleh sebab itu proses-proses tersebut memerlukan pemetaan target dan waktu yang tepat serta jelas. Tujuannya adalah untuk mengetahui prioritas pembangunan mana saja yang mendesak dan memerlukan kebijakan. Karenanya, proses perencanaan pembangunan dilakukan secara bertahap mulai dari satuan organisasi terendah di dalam pemerintahan daerah hingga ke tingkat tertinggi organisasi pemerintahan daerah. Usaha meminimalisir kesalahan sudah dilakukan dalam proses perencanaan, sehingga dalam pelaksanaan pembangunannya, rencana-rencana yang sudah tertuang dalam dokumen dapat terlaksana dengan baik, yaitu efektif, efisien, tepat waktu, dan tepat sasaran.

Pembiayaan adalah transaksi keuangan yang bertujuan menutupi selisih Pendapatan dan Belanja Daerah. Penerimaan Kota Batu berasal dari sejumlah sumber seperti transfer keuangan yang berasal dari dana cadangan daerah, hasil dari penerimaan obligasi dan pinjaman, hasil dari penjualan aset daerah yang dipisahkan, dan SiLPA (Sisa Lebih Perhitungan Anggaran Tahun Lalu). Ada beberapa jenis komponen pengeluaran dalam pembiayaan anggaran daerah antara lain untuk Transfer dana cadangan, Penyertaan modal Pemerintah Daerah untuk Badan Usaha Milik Daerah (BUMD), pembayaran utang pokok yang telah jatuh tempo, pembayaran utang kepada pihak ke tiga, dan sisa lebih perhitungan penggunaan anggaran tahun berjalan. 
Dalam APBD, Pembiayaan Daerah menempati posisi strategis sebagai gambaran transaksi belanja yang akan dilakukan guna mencapai keseimbangan anggaran. Makanya penting, dalam kebijakan Umum untuk meningkatkan sumber pembiayaan daerah adalah dengan cara meningkatkan kualitas dan kuantitas manajemen pembiayaan daerah dengan memperhatikan tingkat akurasi, tingkat efisiensi, tingkat efektivitas dan tingkat profitabilitas penganggaran. Acuannya adalah dalam membuat kebijakan pembiayaan anggaran Kota Batu, maka dipandang perlu untuk menyusun anggaran yang tidak berisiko dan mengganggu stabilitas kesinambungan anggaran pemerintah pusat dan pemerintah daerah. Perencanaan pembangunan juga harus disusun sedemikian rupa untuk menghindari defisit anggaran. Maka proyeksi kegiatan pembangunan harus memperhatikan kemampuan pendapatan daerah. Kegiatan pembangunan dalam perencanaan juga harus disertai dengan berbagai opsi, melakukan reshaping kegiatan pembangunan, memperhatikan prioritas penanganan masalah daerah, dan menyesuaikan keperluan sumber daya (input) program pembangunan atau kegiatan pembangunan dengan keluaran (output) dan hasil (outcomes) yang diperoleh dari hasil pelaksanaan rencana pembangunan.

Ketepatan tujuan dalam perencanaan pembangunan daerah Kota Batu, sudah sesuai dengan tujuan. Pencapaian tujuan dari perencanaan pembangunan di Kota Batu bisa dilihat melalui ketersediaan dokumen-dokumen perencanaan yang kemudian akan dijadikan pedoman oleh Pemerintah Kota Batu dalam melaksanakan setiap program pembangunan.

Dalam penyajian data sebelumnya ketepatan dalam menentukan tujuan merupakan tujuan yang ingin dicapai dan telah disepakati sebelumnya dan biasa dituangkan dokumen secara tertulis dan bersifat strategis, sehingga sangat penting dijadikan sebagai pedoman serta rujukan dalam pencapaian tujuan organisasi terutama dalam jangka panjang.

Perencanaan pembangunan adalah bagian dari rangkaian proses pembangunan yang dilakukan secara menyeluruh. Perencanaan pembangunan memiliki dua makna, pertama, sebagai pedoman dalam pelaksanaan pembangunan. Kedua, sebagai tolak ukur (indikator) kesuksesan pembangunan daerah. Oleh karena itu, penyusunan perencanaan pembangunan daerah bisa dikatakan sukses jika kedua hal tersebut terpenuhi dengan maksimal. Keberhasilan sebuah perencanaan pembangunan, tidak hanya dilihat dari ketersediaan dokumen perencanaan pembangunan, tetapi keakuratan dan hubungan dokumen tersebut dengan kondisi nyata daerah.

Jika dinilai dari RKPD, perencanaan pembangunan daerah Kota Batu bisa disimpulkan bahwa perencanaannya telah berjalan dengan baik. ketersediaan dokumen perencanaan pembangunan tersebut dapat menjadi bukti bahwa Bappelitbangda Kota Batu telah berusaha mewujudkan perencanaan pembangunan daerah kota Batu yang berkualitas.

Dengan ketersediaan dokumen perencanaan pembangunan yang lengkap, pemerintah kota Batu melalui Bappelitbangda berusaha menyusun kerangka kebijakan yang berhubungan, aktual, tepat, dan sesuai dengan kebutuhan masyarakat serta prioritas kebijakan pembangunan daerah. Tersedianya dokumen dimaksud akan menjadi media pengawasan untuk menghindari terjadinya tumpang tindih kewenangan dan tanggung jawab antar leading sector, penyalahgunaan anggaran. Terakhir, adanya dokumen dimaksud merupakan perwujudan akuntabilitas publik dan penyusunan perencanaan pembangunan. Ketepatan tujuan dalam hal ini yaitu mengacu pada dokumen perencanaan. Karena dokumen perencanaan sebagai pedoman dari pembangunan daerah, sehingga dengan ketersediaan dokumen-dokumen perencanaan yang ada di Bappelitbangda Kota Batu, maka perencanaan pembangunan daerah kota batu dikatakan sudah efektif.

Ketepatan sasaran dalam perencanaan pembangunan telah tepat sasaran sesuai dengan yang diinginkan Pemerintah Kota Batu. Di dalam RKPD Kota Batu Tahun 2019, dikatakan bahwa sasaran 
merupakan upaya dalam mencapai setiap misi kepala daerah. Maka, untuk mewujudkannya perencanaan pembangunan harus benar-benar tepat sasaran.

Seperti yang tertera dalam Rencana Kegiatan Pemerintah Daerah Kota Batu salah satu yang menjadi sasaran dari Pemerintah Kota Batu adalah meningkatkan stabilitas kondisi sosial, ketertiban dan ketentraman wilayah dan meningkatkan pelestarian dan pengembangan budaya yang merupakan misi pertama yang menjadi sasaran perencanaan pembangunan daerah Kota Batu. Sehingga jika dilihat dari indikator ketepatan sasaran, perencanaan pembangunan daerah kota batu sudah efektif.

Proses sebuah perencanaan pembangunan daerah memuat unsur yang sangat penting bagi keberhasilan pembangunan daerah. Oleh karena itu, pentingnya perencanaan pembangunan daerah sangat membutuhkan dukungan agar apa yang menjadi tujuan yang telah direncanakan dapat tercapai. Sumber daya dan komitmen yang tinggi sangat dibutuhkan dari setiap elemen yang terlibat dalam proses perencanaan.

\section{Dukungan dan Hambatan Efektivitas Penyusunan Perencanaan Pembangunan Pemerintah Kota Batu}

Ada beberapa faktor yang menjadi pendukung efektivitas perencanaan pembangunan daerah kota batu, yaitu adanya konsistensi terhadap waktu dalam perencanaan. Selain itu, faktor lain yang menjadi pendukung adalah komitmen dari kepala daerah, kepala OPD dan elemen lain yang terlibat dalam proses perencanaan dan Kota batu memiliki wilayah yang kecil akan sangat mudah untuk menyatukan apa yang menjadi aspirasi masyarakat Kota Batu.

Faktor-faktor penghambat efektivitas perencanaan pembangunan daerah Kota Batu adalah program kegiatan yang tidak sesuai dengan RPJMD dan adanya visi-misi lain yang tidak sama dengan visi-misi kepala daerah, sistem belum tersinkronisasi secara sempurna atau maksimal, sehingga proses input data masih perlu berulang-ulang dan sistem belum berfungsi secara maksimal juga masih menjadi faktor penghambat efektifnya perencanaan pembangunan Daerah Kota Batu.

\section{PENUTUP}

Berdasarkan hasil pembahasan di atas, diperoleh kesimpulan bahwa efektivitas perencanaan pembangunan daerah kota batu berdasarkan indikator ketepatan waktu di Kota Batu sudah efektif. Sementara, efektivitas anggaran/perhitungan biaya dalam perencanaan pembangunan daerah kota batu tahun 2019 bisa dikatakan belum efektif, karena masih terjadi defisit terhadap anggaran belanja daerah. Sedangkan dari sisi ketepatan tujuan dalam perencanaan pembangunan daerah kota batu tahun 2019 sudah efektif. Hal ini bisa dilihat dengan tersedianya dokumen-dokumen perencanaan yang merupakan tujuan dari kegiatan perencanaan pembangunan daerah kota Batu. Demikian juga dengan ketepatan sasaran dalam kegiatan perencanaan oleh Pemerintah Kota Batu sudah cukup tepat. Sinkronisasi kepentingan pembangunan nasional, provinsi Jawa Timur, dan pemerintah Kota Batu sudah terhubung dengan baik.

Walaupun secara keseluruhan proses penyusunan perencanaan pembangunan cukup efektif, namun masih ada faktor faktor penghambat yang harus diperhatikan oleh pemerintah kota Batu yaitu program kegiatan yang tidak sesuai dengan RPJMD atau visi-misi kepala daerah, sistem ditingkat lokal pemerintahan daerah yang belum tersinkronisasi secara sempurna atau maksimal, sehingga proses input data masih perlu berulang-ulang. Kurangnya koordinasi antar OPD juga masih menjadi faktor penghambat efektifnya perencanaan pembangunan Daerah Kota Batu. Oleh sebab itu diperlukan konsistensi dari semua elemen yang terlibat dalam perencanaan. Komitmen dari kepala daerah, kepala OPD dan elemen lain yang terlibat dalam proses perencanaan harus diperkuat. Luasan 
wilayah yang relatif kecil dibanding daerah lain sedikit banyak akan membantu dalam menyatukan kepentingan masyarakat Kota Batu.

\section{DAFTAR PUSTAKA}

Mahi, I. A. K., Trigunarso, S. I., \& SKM, M. K. (2017). Perencanaan Pembangunan Daerah Teori dan aplikasi. Jakarta: Kencana.

Makmur (H.). (2011). Efektivitas kebijakan kelembagaan pengawasan. Bandung: Refika Aditama.

Mardiasmo, D., \& MBA, A. (2009). Akuntansi Sektor Publik. Yogyakarta: ANDI.

Moleong, L. J. (2019). Metodologi penelitian kualitatif. Bandung: PT Remaja Rosdakarya

Peraturan Daerah Kota Batu Nomor 3 Tahun 2018 Tentang Rencana Pembangunan Jangka Menengah Daerah Tahun 2017-2018.

Peraturan Daerah Provinsi Jawa Timur Nomor 3 Tahun 2014 Tentang Rencana Pembangunan Jangka Menengah Daerah.

Peraturan Pemerintah Daerah nomor 3 tahun 2004 Tentang Pembagian Urusan Pemerintah Daerah Provinsi dan Pemerintah Kabupaten/Kota.

Peraturan Pemerintah Nomor 41 Tahun 2007 Tentang Organisasi Perangkat Daerah.

Sugiyono. (2010). Metode penelitian kuantitatif dan R\&D. Bandung: Alfabeta, CV. . (2018). Metode Penelitian Kuantitatif, Kualitatif dan R\&D. Bandung: Alfabeta, CV.

Syafiie, Inu Kencana dan Welasari. 2015. Ilmu Administrasi: Yogyakarta: Pustaka Pelajar.

Undang-Undang Nomor 23 Tahun 2014 Tentang Pemerintah Daerah.

Undang-Undang Nomor 25 Tahun 2004 Tentang Sistem Perencanaan Pembangunan Nasional. 